\title{
Primo Bartolini and the "Eye-talians" of Nashville: Becoming American in the Athens OF THE SOUTH
}

\section{Matteo Brera}

Abstract: This essay describes how the Italians who settled in Nashville between the end of the nineteenth century and before the outburst of the First World War favoured first and foremost their occupational mobility thus prioritizing their integration in the economic fabric of a thriving city. Initially, they kept their cultural heritage alive but aimed to gain solid knowledge of the English language and American customs in order to apply for American citizenship as soon as possible, thus avoiding the severe discrimination endured by other Italian communities in southern states.

Among the Italians of Nashville, Primo Bartolini stands out as a unique example of successful cultural and social hybridization and of the making of Italian American identity in Nashville and the South. Bartolini moved to Music City in 1908, after a short experience as a teacher in Indiana, and he was the first non-native of Tennessee to be drafted in 1917 to serve for his adoptive country during the First World War. A poet and a scholar, he wrote more than 300 poems on nostalgia, love, and patriotism. In these unpublished works, Bartolini shows how his identity progressively became Americanized: his writing style changed over time while still maintaining certain prosodic elements proper to his Italian culture and education.

Bartolini's experience, along with those of his compatriot who found their new home in Nashville, also confirms the integrating effect that the Great War had on Italians. Indeed, in the United States, a blend of old loyalties and the strong desire for acceptance and recognition drew the entire community into the public life of their adopted cities.

According to the United States Census for the year 1900 and the Dillingham Commission Report prepared by the Immigration Commission between 1907 
and 1911, the 1,222 Italians who had settled in Tennessee represented 6.9\% of the total foreign-born population of the state. ${ }^{1}$ The report also stresses how these first Italian communities were "very fully" Americanized in 1911 and how their clothes were "similar to those worn by the laboring America." Their houses were also "well-furnished and equal to any American house in the farming section" (Dillingham 388).

Furthermore, the government officials pointed out how some Italians who settled north of Nashville, in a rural area known as Paradise Ridge (today Joelton), also built a small church and remarked that a priest travelled from Nashville on the last Sunday of each month to hold mass. The services, continues the report, were in English and those Italians had "picked up enough of the language to be able to understand it." Moreover, almost all the Italians in the area had taken out their full citizenship papers and were "spoken of as being honest and truthful" (Dillingham 388).

Several such remarks throughout the Dillingham papers betray, from a rhetorical point of view, the U.S. Government's attitude toward the different "races" that immigrated to America and that were regarded as intrinsically inferior to native whites. Indeed, the reporters often patronizingly linger on the "progress" made by the new aliens, making statements such as those in the remarks quoted at the beginning of this paper about the full and proper Americanization of Germans and Italians.

The report confirms how, despite efforts by many southern governments to attract immigrants between 1850 and early 1900, the foreign-born population of the South and, more specifically, of Tennessee remained quite low compared to that of the most populous states of the Northeast. Furthermore, the South offered few of the industrial jobs preferred by the immigrants, and southern states were a long and expensive train ride away from the main port of entry of Ellis Island. Finally, the presence of millions of African Americans kept Italians away

\footnotetext{
${ }^{1}$ See Brera, "Italiani in Tennessee" 76-77. A total of 2,517 persons of Italian origin were living in Tennessee at the beginning of the twentieth century, if we consider the 1,295 first-generation Americans with one or both parents born in Italy (National Archives, I, I, CLXXIV_CLXXV). The Dillingham Commission, named after its chair, Vermont Senator William Paul Dillingham, was formed on February 20,1907, in response to concerns regarding the growing population of immigrants, which reached 1,285,349 units that year. The Dillingham Commission's job was to decrease this number. The commission was composed of three senators, three members of the House of Representatives, and three presidential appointees.
} 
from states where labour competition with other poor and marginalized people threatened their possibilities of social betterment. ${ }^{2}$

The above facts portray a nation in which racism was still a serious issue at the beginning of the twentieth century. Although evidence of the marginalization of the first Italian settlers in Tennessee is limited to the government reports and includes documents related to other nearby areas and states, immigrants from Mediterranean Europe who settled in the Volunteer State were probably treated like their counterparts in other southern states, such as Alabama and Louisiana. ${ }^{3}$ In the context of the racial issues that affected the South in the first half of the twentieth century, the Italian community of Nashville represents an interesting example of successful cultural and social hybridization.

This essay shows how the integration sought by the Italians of Nashville prioritized economics over everything else and how these Italians aimed to learn English first and foremost to favour their occupational mobility. Initially, they kept their cultural heritage alive but aimed to gain solid knowledge of American customs in order to apply for American citizenship as soon as possible.

Among the Italians of Nashville, Primo Bartolini stands out as a unique example of the making of Italian American identity in Nashville and the South. Bartolini moved to Music City in 1908, after a short experience as a teacher in Indiana, and he was the first non-native of Tennessee to be drafted in 1917 to serve for his adoptive country during the First World War. ${ }^{4}$ A poet and a scholar, he wrote more than 300 poems on nostalgia, love, and patriotism. In these unpublished works, Bartolini shows how his identity progressively became Americanized: his writing style changed over time while still maintaining certain prosodic elements proper to his Italian culture and education.

Together with those of his compatriots in Nashville, Bartolini's case also confirms the integrating effect that the Great War had on Italians: in this land, a

\footnotetext{
${ }^{2}$ See Norrell 98-99.

${ }^{3}$ For detailed accounts and anecdotes of the racial question in the nearby Italian community of Birmingham, Alabama, a city economically linked with Nashville and the main coal and steel industrial production hub for the Tennessee Coal, Iron and Railroad Company (TCI) until the early 1920s, see Aguglia Beaver 18; Coleman Ellison 34-47; and Fede 236-238. On the much more violent conflicts between Italians and African Americans in Tallulah, Louisiana, see Deaglio 74-76.

${ }^{4}$ Bartolini's decision to move to Nashville is not clarified in the available sources and oral memories.
} 
blend of old loyalties and the strong desire for acceptance and recognition drew the entire community into the public life of their adopted cities. ${ }^{5}$

\section{Nashville's Italians}

Regrettably, not much is left of the records and papers belonging to the Italians of Nashville, and it has proved difficult to establish when the first "Eye-talians" (as they were often derogatorily addressed, according to John Rebori's unpublished account of the early Italian communities in Knoxville, Tennessee) arrived in town (Rebori 23). ${ }^{6}$ However, documentary evidence suggests that a new chapter in the story of the Italian community of Nashville unfolded in 1908, when an Italian Union was granted chartered association status by the State Registrar of Tennessee. ${ }^{7}$ The application for the charter cites that the organization's specific purpose was "the social enjoyment, intellectual and moral betterment of the Italians of Nashville and its environs, and the promotion of good citizenship" ("For Betterment of Nashville Italians").

The Association's chair, Evaristo V. Ghidoni, played an important role in the integration process of his fellow Italians. In the aftermath of the official recognition of the Italian Union by the State of Tennessee, Ghidoni, who is described in a newspaper article as "a cultured and most entertaining Italian gentleman who has decided to make Nashville his permanent home," started a weekly free night school where he taught Italian classes. The Italian Union then counted about 30 members who gathered on Sundays in "a beautifully fitted-up hall on Broadway" to listen to Ghidoni's speeches ("Free Night Schools for Local Italians").

In an interview published in The Nashville Tennessean, Ghidoni claims that his fellow citizens "should be better informed about the country in which they live and that they should have a clearer understanding of politics so that they may be more intelligent as voters" ("Free Night Schools for Local Italians"). This attitude shows a clear commitment by the newly founded Italian Union to foster

\footnotetext{
${ }^{5}$ As confirmed, among others, by Sterba 33.

${ }^{6}$ A small number of Italian settlers were reported living in the Nashville area between 1819 and 1907. See Brera, "Italiani in Tennessee" 80-83.

${ }^{7}$ Members of the association were Evaristo V. Ghidoni (President), Filippo Serafini, Leonardo Vecchione, Casimiro Zenoni, Vito A. Cerruti, Geraldo Cianciolo, Filippo Rotella, Antonio Mottola, and Silvestro Mazza (Charter records).
} 
the Americanization of its members, which made up approximately $50 \%$ of the Italians native of Nashville in 1908. Immigrants were encouraged to learn the local language and to become familiar with rules and politics, which would enable their civil engagement, economic inclusion, and, ultimately, social mobility. According to the interviewer, Ghidoni was "an accomplished linguist" who spoke and read "several languages" fluently. He had learned English himself only recently through his American wife and strongly felt that the language spoken in America would soon become "the language of the world," especially with regard to commercial and social purposes ("Free Night Schools for Local Italians").

While the Italian community of Nashville was trying to blend in-and, as we learn from documentary evidence, earning a good deal of respect from Tennesseans in the process-its members did not lose their ties with the motherland. In 1908, one of most violent earthquakes in history partially destroyed Messina and Reggio Calabria, claiming about 120,000 lives. The Italian community of Nashville responded by appointing several committees to canvass the city in order to raise funds to be sent to Italy. In a couple of days, the Italian Union raised the considerable sum of $\$ 620.35$, receiving significant help from the people of Nashville, including the non-Catholic population. According to Ghidoni, who claimed to be the only Italian protestant in town, the whole Italian community (including Northerners and Southerners who were attached to very different local customs, loyalties, and traditions) set aside their parochialism and rivalries to offer some relief to the victims in Sicily and Calabria. The fundraising also led to official recognition of the small but very active Italian colony of Nashville "by Italian authorities in Washington and New Orleans" ("Italians Send Aid Across the Sea"). By 1909, when Ghidoni called further meetings of the Italian Union to raise funds for the stricken areas in Italy, the number of Italians living in Nashville had increased to 300. Thanks to the Italian Union's efforts, at the beginning of 1909 the Italian ambassador in Washington received a cheque for \$1,028.90 ("Nashville Italians to Meet Sunday").

While the Italians of Nashville were growing in numbers, the First World War broke out, but the United States was not involved initially in what was regarded as a matter to be dealt with by European governments and armies alone. When, in 1917, President Woodrow Wilson announced that the country would enter the war, the Italians of Nashville responded with ardent declarations of patriotism: the young Domenico (Dominick) Petruccelli from Naples and the former garibaldino Carlo Zenoni from Bergamo, both first-generation immigrants to Nashville, 
publicly stated their intention to respond to President Wilson's call and enlist in the U.S. Army. Petruccelli and Zenoni were both leading members of Nashville's Italian Union: the first had served in the Italian army in 1906, returning to the Peninsula only two years after he had left it at age 17 . On his first tour, he was sent to Reggio Calabria and Messina for earthquake relief and subsequently he patrolled the area around the Vesuvius during the eruption of 1908. Zenoni had volunteered under Garibaldi and served in the campaigns of 1866 and 1870 against the Austrians. Like Petruccelli, Zenoni was a naturalized American and he was eager to be a U.S. soldier in spite of his advanced age ("Italians Ready to Join the Army"). ${ }^{8}$

The example of Italian American patriotism set by these two leaders of Nashville's Italian colony did not remain an isolated case: a young man from Modena would soon become the first foreign-born resident to volunteer in the United States Armed Forces in times of war.

\section{Primo Bartolini: An Italian American Flag Raiser and Poet Laureate}

Primo Luigi Bartolini was born in Fanano, in the Apennines region between Bologna and Florence, on May 10, 1889. He had arrived in Nashville seven years before the assassination of Archduke Franz Ferdinand by Gavrilo Princip and the consequent outburst of the First World War. Ellis Island's arrivals records show that he was admitted to the United States on November 20, 1907. An alumnus of the University of Bologna, where he earned his degree in literary studies, Bartolini was awarded a Bachelor of Arts degree from Conception College, in Missouri, before finally moving to Nashville. ${ }^{9}$

Bartolini's relocation to Tennessee is somewhat mysterious. According to his arrival records, in which he is registered as a student and unskilled labourer, his final destination was to be Covington, Indiana. Like many "birds of passage" - immigrants who left the Old World with a view to return home as soon as they had made enough money to secure a future for their families-Primo left in Italy his wife, Maria Cardinale, from Naples, whom he had married a few months earlier.

\footnotetext{
${ }^{8}$ Eventually, neither Petruccelli or Zenoni enlisted, at least according to available documents.

${ }^{9}$ His education also included a degree at a "St. Charles University (Switzerland)." No information is available on the subject studied at what seems to have been a private Swiss college. According to Francesca Bartolini, Primo's daughter, her father could have obtained a degree in philosophy and French, one of the five languages in which he was fluent, while in Switzerland.
} 
While in Indiana, Bartolini taught modern languages for a short while and soon left Fountain County to attend college in Missouri. Four years later, his name is on the Nashville City Directory, where he is listed as a baker residing at the luxurious Hermitage Hotel, Downtown. How an unskilled baker who did not work at the Hermitage could live in Nashville's recently opened "First Million Dollar Hotel" (Wills II) is a mystery that the presently available documents do not explain. However, according to Primo's daughter, Francesca, whose recollections of her father's life have been invaluable for uncovering otherwise untraceable aspects of Bartolini's biography and poetic accomplishments, he was an undercover agent for the U.S. Government. ${ }^{10}$

In Nashville, Bartolini's career took off quickly: only two years later he was employed as a modern languages teacher at Boscobel College for Young Ladies. ${ }^{11}$ The school closed in 1914, and Bartolini dedicated a long poem to it ("Boscobel"). These verses display a few traits that can be identified in his poetic production, which amounts to over 300 unpublished poems:

Happy in its solitude so dear,

In a new dazzling nature style,

Breathing life under southern skies,

Sweet Boscobel, to you my smile.

[...]

Words are carved on poplars and oaks,

Monograms and dates and dreams of boys,

Which bring a glimpse of the romantic past,

Sweet Boscobel, to you my voice.

$[\ldots]$

Breathe in me new strength, Alma mater,

Cherish my soul, lead me sadly along,

${ }^{10}$ Interviews with Francesca were held in 2012 and 2013 at her Nashville house. Primo Bartolini's involvement in government activities is confirmed by one record retrieved in the Nashville Public Library (NPL) where Primo is listed as a former "narcotics investigator" for the Department of Justice ("Mrs. Bartolini Services Today"). I wish to thank Beth Odel for her assistance throughout my research at the NPL.

11 Founded in 1889 as the Nashville Baptist Female College by the Tennessee Baptist Convention, Boscobel College operated for 25 years until 1914. One of its founding objectives was to provide higher education for young women at the lowest possible cost. See Fleenor 63. 
That I may gain my youthful dreams,

Sweet Boscobel, to you my song.

This and many other poems written by Bartolini throughout his life were stored away in shoeboxes and lay unread for more than 50 years in Francesca Bartolini's house in Nashville. The poem, dedicated to his first place of employment as a teacher in Tennessee, reveals an idyllic and nostalgic vein, which characterizes most of Bartolini's early production. It suggests an adherence to the most flexible of Italian metric structures: the quatrain of octosyllables (quartina di ottonari), a plainly musical rhythm with a discontinuous phonic pattern. Bartolini privileges a verse canonized in Italian poetry in the 1300s and 1400s and consistently present in the Italian tradition, notably in the works of Gabriello Chiabrera and Giosueè Carducci; in fact, the latter had been Bartolini's most influential teacher at the University of Bologna. As in many popular poetic schemes, rhyming couplets dominate the poem and are surrogated by assonances when two rhyme-words cannot be designated, like in the second quartet (oAkS:pASt; boyS:voiCE). Bartolini privileges a poetry of feelings, and the poetic voice is that of an Italian who is already finding comfort "under the Southern skies" and is fond of his new "Alma mater," an expression through which the longing for his Bolognese university years surfaces.

This double tension between nostalgia for the motherland and a sense of deep commitment to becoming an American is evident in many of his poems, which constitute the fragmenta of his journey from Italianness to Americanness. In Bartolini's poetry, Italy is a land far away ("My home port, / Is far away" ["A Little" 7]; "My home is far away" ["Blue Violet" 4]), and so are his village and the old house in the Apennines ("Oh! Solitary, my little home, / Lost in the darkness of the Valley, / Hidden by the pines and chestnut trees, / Far from thee, no Christmas cheer from me" ["Alone" 7-10]; "From that sweet land, / So fair to see" ["Break, Break O! Sea [sic]" 8-10]; "Far land, fair hill, my hill” ["Far Land" 1]). The "lonely cottage" left behind when he sailed to America ("Good Bye") is often the protagonist of Bartolini's poems, as are the familiar landscapes of the Modena hills, which he recalls through the vision of America's natural elements ("Roll on, roll on, my little river, / The blue notes are in my brain, / In thy ripples I see my home, / Which I long, but all in vain" ("My Little River" 5-8). The blue of the Italian sky is often juxtaposed to the darkness of the ocean's waters, which are regarded by the immigrant as a graveyard for his hope and his past: "[...] Buried by 
the tide of thy wave, / Unkissed, without a farewell, / In thy watery mystic grave" ("Ocean" 9-12). Although painful, the sea-crossing represents a path of hope, to which the poetic voice abandons itself:

The land is out of view

The wind blows on the deep,

Black fogs are on the sky,

The cold night needs to sleep.

[...]

Fear not, my restless soul

The dark and the unknown.

Go forward with your dreams,

In silence and alone. ("Fear not" 5-12)

Once Bartolini immigrated to the new country, his poetry moved along three paths. The first is the already mentioned poetry of nostalgia, in which many of the compositions are dedicated to members of his family, including his dead brother, to whom he offers a sonnet (almost an emulation of Ugo Foscolo's "Un dì, s'io non andrò sempre fuggendo"), and, most importantly, his mother: "When sunsets burn and die, / I long to be / Near my mamma over there / Across the sea" (“Mamma” 1-4).

The second poetic path is that of integration, as Bartolini begins to admire the new land (as evidenced by the poem dedicated to Boscobel College) and its people and places, which are incapable, however, of replacing the memories and beauties of the homeland in the poet's heart:

O Nashville roses, O Southern flowers, Smile, smile, while I look at thee and sigh,

$\mathrm{O}$ roses and violets, I love thee,

Though you grow too far from my Latin sky. ("Roses" 9-12)

The poet here evokes a syntagm of the Leopardian tradition: the "roses and violets" of Giacomo Leopardi's "Il sabato del villaggio," one of the most famous lyrics of popular Italian poetic heritage. Moreover, the tone of Bartolini's verses is not as gloomy as in his nostalgic poems, since he invokes the smiling flowers of the South. 
Bartolini's third poetic path is marked by patriotism; the most significant poem he composed in this period is titled "My Italian Flag":

My flag has neither stripes nor stars,

And it waves where my fathers lie;

Sign of rebellion and of peace,

It shines under a Latin sky. (1-4)

The longing for home, for the Italian sky, is soothed by the proud recollection of the colours of the Italian flag, which still represents the one and only native land for Bartolini.

A few years later, Bartolini's poetry took a decisive turn that followed and underlined his Americanization process, as the outbreak of the First World War was to be a pivotal factor in the moulding of his American identity. This gradually confined Bartolini's Italian patriotic spirit into a recess of his memory.

\section{The Poet-Soldier}

After his appointment at the Boscobel College for Young Ladies ended, Primo Bartolini spent a couple of years working, first as a cook (Nashville City Directory 1915) and then as a waiter at Antonio Petruccelli's chili parlour (Nashville City Directory 1916), before the war frenzy spread through the country. When President Wilson promulgated the Selective Service Act of 1917, under which all males aged 21 to 30 were required to register for military service, Bartolini showed no hesitation and volunteered. His number (854) was drafted and he became the first foreign-born resident to be selected in Tennessee. He put into verse his feelings concerning the important chance of serving under the Stars and Stripes:

I shall go with a thousand boys

To fight across the sea.

Oh! Let Old Glory wide unfurled

Over my path and me.

The time has come to do our part,

Young dreams of yesterday, 
Oh! Listen to the bugle's call-

They summon us to-day.

Each door, each window waves a flag,

Our Nation's love is known,

And here and there a thousand cheers,

The boys are marching on.

I go; will I tread my last way?

For freedom let it be;

And let Old Glory dearly smile,

Over my heart and me. ${ }^{12}$

Again, Bartolini's poetry is "of the heart." But, in this case, it is also primarily "of the flag," as evidenced by the reference to "Old Glory," the name given to the Star-Spangled Banner by William Driver in 1824 when he commandeered his first ship. The reference to the flags—both the Italian and the American-is a key feature of Bartolini's poetry: in this poem, which, according to the press, was "composed on the moment" when he was drafted ("Primo Bartolini Drafted: Proud to Serve Country"), the national symbols confer a rhetorical circularity to his verses. The description of a country ready to fight revolves around the image of the flag, which flies outside every window to symbolize both the blessing and the love of America for its sons (the "boys"), among whom Bartolini marches on. The reference to the sea is also worthy of note: in the eyes of an immigrant who had crossed the Atlantic to find a new life in a foreign country, the act of sailing back to the Old World to fight for freedom is a supreme sacrifice that leads to giving up the old "dreams of yesterday" (1. 6) for a future as yet unknown.

From then on, Primo Bartolini's popularity surged among Nashvillians (and beyond) and he became a prominent Italian in the area. The local press lauded him as the most fervent non-Tennessean patriot, imbued as he was with "celestial fire, [...] passion, wisdom and philosophy" (“Silk Flag Given to Primo Bartolini”). His speeches to the Italian Club became more frequent, especially after the Italian

12 This untitled poem was published in the newspaper article titled "Primo Bartolini Drafted: Proud to Serve Country" (1917). 
debacle of Caporetto. ${ }^{13}$ In an inspirational public speech, he stated that the people of Italy, the liberals, and even the pro-Austrian Pope, Benedict XV, had agreed "to wage a united war on the Kaiser and his government" after the crumbling of the Italian front ("Says Italians Are Now United"). Bartolini thus became the best representative of "hatred for kaiserism" and, when he was invited to speak to the soldiers on furlough, his rhetoric soared to an even higher pitch of Italian American patriotism:

What are the trenches of Flanders? What is the wild winter of $\mathrm{La}$ (sic) Piave? What are the few thousand miles of sea between you and the land that gave you birth? No matter if the skies are blue or dark as long and wherever the stars and stripes wave about you there is home, and there is a place for you to be at your duties. ("Silk Flag Given to Primo Bartolini")

After Bartolini's speech, James Mottola, a well-known Italian tailor in Nashville, presented Bartolini with a "beautiful Italian flag made of silk" that bore "five stars in honor of five nephews of Primo" ("Silk Flag Given to Primo Bartolini") who were in active service on the Piave front. ${ }^{14}$ Now regarded as "a prominent Italian of Nashville," Bartolini composed a poem in blank verse resembling a canzone about the "anguish and sorrow" of war but also the "fire of patriotism" ("Local Italian Has Hope for Country"):

Tonight the cannon roars, and roars

On the Venetian plain;

\footnotetext{
${ }^{13}$ The Battle of Caporetto (also known as the Twelfth Battle of the Isonzo, the Battle of Kobarid, or the Battle of Karfreit, as it was known by the Central Powers), took place from 24 October to 19 November 1917. Austro-Hungarian forces, reinforced by German units equipped with poisonous gas, broke into the Italian front line and routed an army that had practically no mobile reserves. Caporetto is commonly regarded as the most ruinous defeat in the history of the Italian army.

${ }^{14}$ Italy's defeat at Caporetto led to General Luigi Cadorna's dismissal. General Armando Diaz replaced him as commander of the Italian Army and set up a strong defence line along the Piave River, where Italian troops were joined by small reinforcements sent by France and Great Britain. The Piave line, which was strenuously defended by the Italians, was regarded as the last bulwark against the Central Powers and was the theatre of the decisive victory of Diaz's troops: the legendary Battaglia del Piave, fought between 15 and 23 June 1918.
} 
The air is thick with clouds of smoke;

My sky has lost its blue.

The Piave river and the Brenta are red with blood,

Towns are ruins and homes are dust.

[...]

O Garibaldi's soul, where art thou?

Come and take the field again,

[...]

The Laguna is dumb and dark;

Venice, once so gay, is dull and sad;

No more the barcarola's songs;

The lovely serenadings $[s i c]$ down the canal [...]. ("Tonight the Cannon Roars")

Under the aegis of the most popular of Italian Risorgimento patriots, Giuseppe Garibaldi, Italy should have brought together all of its conflicting parties in a closer tie of national pride and honour. Along with Garibaldi's spirit, Bartolini summons the well-known classical Petrarchan and Leopardian topoi of the once-glorious land now reduced to "smoke" and "dust": modern ruins that are obfuscating the beauties of Venice and the sky of Italy, fondly remembered as "blue." In Bartolini's poetic voice, the sense of belonging to his motherland surfaces strongly, although only briefly. In fact, the roaring cannons of the American "boys" ("For a million boys will come / Far, from across the sea, / America, America, thy sons!" [32-34]) had come to rescue the Italians, whose veins were filled with "Roman blood" (18; another classical topos), and to free them from the "barbarian legions of the Huns" (21). The predominance of the new Americanized spirit is clear as the poem blasts the loathed (by Bartolini and the Allied Forces) Austro-Hungarians, the "foe" that threatens the cities of "Asiago, Feltre, Udine, Cividale, names so dear" (43) and the "hills and fields" where the poet "ran, played and dreamed" (44).

The positions taken by Bartolini became extreme in regard to the "antiHuns" policies that were adopted by America. In one of his public speeches, Bartolini stood as "the only one in the South who patriotically dared to denounce the teaching of the German language" ("Opposes Study of German Language"). In a shocking declaration made to the members of the Italian Union-who fully endorsed his views-Bartolini stated that he had proposed a motion to the Board of Education of Nashville to stop the teaching of a language that could affect 
children's minds. In fact, he stated that "what can't be taught can't be read," and since language, in his views, was a "stronger tie than blood," the authorities should have prevented the teaching of a dangerous means for the "absorption" of German ideas and customs:

The German language is of no practical value and its study is dangerous because it is a vehicle of harmful propaganda. Nashville, 'The Athens of The South', the recognized educational center of the entire South, should have led the way in this important movement. ("Opposes Study of German Language")

A few weeks before he gave this speech, in which he clearly revealed an increasingly ethnocentric attitude, Bartolini had set another example of affection for his new homeland. He bought $\$ 1,000$ worth of war-saving stamps, proudly pointing out that "[a]ny man that loves his family and his country should buy stamps for two reasons: $[\ldots]$ for the profit coming to him $[\ldots]$ and $[\ldots]$ for the patriotic duty that every loyal citizen should perform" ("Primo Bartolini Buys Savings Certificates").

Few days later, he was again the talk of Nashville and the whole of America after winning a prestigious poetry contest. The New York Sun awarded Bartolini the first prize at the "Sock Song Contest," the competition dedicated to "patriotic knitting" compositions. ${ }^{15}$ Bartolini accompanied his entry with the following statement, in which he displayed his sentiment for his adoptive country: "I am an Italian, but now am a citizen of this Country. I am within the draft and await with pleasure my call. I am indeed glad to do my part fighting the Huns." The 10-line poem that earned him first prize and an alleged congratulatory note from President Wilson himself is the following:

Because she knows that I must go

Quite patiently she knits for me,

Long khaki socks to ease my feet,

On mountain roads in Italy,

Way over there.

\footnotetext{
${ }^{15}$ During the war, knitting socks, sweaters, and other woolen garments for soldiers on the front became the occupation (seen as a sort of national service) most engaged in by American women. In 1918, the New York Sun started a poetry contest with the aim to "stimulate both this patriotic knitting and the composition of poems about it" (Van Wienen 214).
} 
With every stitch she knits a thought,

With which a little wish is cast,

And I know all its meaning too-

To come back safe to her at last

From over there. ("Because")

Bartolini projected his poetic vision into the interstitial memory space situated between his faraway Italian identity and his strong patriotism for the United States. The two feelings are mediated by the traditional image of the beloved woman, a consolatory and almost maternal figure that links the Motherland (now located far away, in space and time- "over there") with the new Fatherland. Once more, the imagery draws on a typical allegory of the Risorgimento, the period of Italian unification when the seamstress (cucitrice) became an icon of Italian identity. ${ }^{16}$

The big day arrived at the end of July 1918: Primo was called to colours and left Nashville for Vancouver Barracks, Washington. His board recommended him as a preacher or a teacher, given his mastery of five foreign languages. He gave a short interview to The Nashville Tennessean expressing his desire to fight in Italy, where some of his relatives were already defending the Italian borders on the Piave line ("Primo Bartolini Leaves for Vancouver Barracks"). In Vancouver, Bartolini was named instructor in French "for twenty lieutenants," as he confirmed to his long-time friend, former employer, and fellow patriot Antonio Petruccelli ("Primo Bartolini Leaves for Vancouver Barracks").

At the barracks, Bartolini engaged in more Italian-American patriotic initiatives: he founded the Armando Diaz Italian American Patriotic Union, of which he became president. In this capacity, he sent a wire to President Wilson on the anniversary of the meeting between King Victor Emmanuel III and Garibaldi at Teano (26 October 1861), during which "the Hero of the Two Worlds" officially consigned Southern Italy to the King, sealing the political Unification of the Italian peninsula:

Today is sacred to every Italian heart. Old Glory waves side by side with the tricolors. We Italo-Americans at Vancouver Barracks thank you for the assistance given to our mother country. We feel proud of your leadership. Great is the task that America has undertaken,

\footnotetext{
${ }^{16}$ Two paintings by Odoardo Borrani are iconic in this respect: Il 26 aprile 1859 (1861, Private collection) and Le cucitrici di camicie rosse (1863, Private collection).
} 
but greater will be the reward. We are sure that the dawn of the next Italian independence day will not only renew Italy's independence but will make all the world free and safe for democracy. ("Primo Bartolini Is Head of Diaz Club")

The war ended on 11 November 1918 and Primo was sent to Camp Pike, Arkansas, before being discharged. He never managed to travel to Italy to fight on the Piave line; however, he believed that Italy's contribution had been pivotal for the defeat of the "Huns." He described the joy of the Italian American soldiers at the news of the armistice in this way:

I carried an Italian flag that a hundred of our soldiers had bought, each one contributing with 50 cents [...]. It was the largest and the most beautiful banner $[\ldots]$. We Italians [...] feel that the victory is so largely our own making. ("Proud of Part Italy Played")

A few days later, he returned home to Nashville.

\section{A True American Patriot}

The experience of the war had stirred different emotions in Primo Bartolini, even though his cantonment in Vancouver was several thousands of miles away from the front. In 1918, when the veteran returned to Nashville, he had gained fame as a national poet-patriot, mainly after winning the "Sock Song Contest" advertised by the New York Sun. During the years when his civil and political commitment increased, the press and Bartolini's fellow citizens hailed Bartolini both as "a prominent Italian of Nashville" and as "a martial American poet" ("Local Italian Has Hope for Country, "Nashville Bard Awarded Prize," "Primo Bartolini Is Head of Diaz Club").

After the experience of the war, Bartolini publicly channelled his Italian patriotic feelings toward his adoptive country; his revolt against the invaders and defence of the homeland's sacred borders from the enemy accompanied a shift in his identity from Italian to American.

Bartolini signed his naturalization papers and became an American citizen in 1921, thus rejecting the authority of Victor Emmanuel III, who had knighted him for his services to the Italian cause during the Great War a few months earlier. 
Among the founders of the Nashville Conservatory of Music, directed by fellow Italian Gaetano Salvatore De Luca, Cavalier Bartolini was now regarded as a leading scholar in the South. ${ }^{17}$ In the early Thirties, while Bartolini was being considered for the chair of Modern Languages at Vanderbilt University, his wife Maria Cardinale travelled from Naples to Tennessee to finally join him. Together they bought a plot of land at 511 Fifth Avenue South in Nashville. The new Poet Laureate of The American Legion (Post 5) and his wife could not have chosen a better place to match Primo's fame as an untiring patriot, because it was the very same lot on which the dwelling of Captain William Driver had once stood. ${ }^{18}$

An admirer of the old seaman, Bartolini found that the foundations of the former house were still intact and, while excavating them, he came upon a long narrow stone with the name "Driver" carved in it (Cullom 9). He subsequently decided to use a great deal of stones dug out of the ruins of Driver's old home to build his own house, a rectangular structure whose walls included stones that Bartolini collected from Independence Hall and from the tombs of presidents Washington, Jefferson, Jackson, Polk, Lincoln, Grant, Garfield, McKinley,

${ }^{17}$ According to a small number of sources, including his daughter oral testimony, Bartolini was knighted by King Victor Emmanuel III as a Cavaliere della corona d'Italia (Knight of the Italian Crown), the first "national" decoration instituted by the Kingdom of Italy. This detail is highlighted in the official Catalog of the Nashville Conservatory of Music, where Primo Bartolini's short biography and achievements are explained (on page 23). Finally, in a short article published in The Nashville Tennessean on 10 December 1924, it is confirmed that Bartolini "received the Cross of the Knights of the Crown [...] by King Victor Emmanuel III, through the minister of Foreign Affairs in Rome, in recognition of service he gave to the Allied cause during the World War." The article has no title and is unsigned.

18 William Driver (1803-1886) was a 34-year-old widower and former merchant sea captain when he arrived in Nashville from Salem, Massachusetts, in December 1837. He brought with him his three young children and his cherished United States flag, which he had named "Old Glory." It had been made by his mother and the "girls of Salem" and presented to him on his twenty-first birthday. A fervent American patriot, Driver stood with the Union in Nashville when the city was under the control of the Confederates, who threatened to seize his house to take the flag. To save it from destruction, Driver allegedly hid the flag until late February 1862, when the Union forces took Nashville, with the help of loyal women neighbors who sewed "Old Glory" into a coverlet. Soon after the Union Army entered the city, Driver went to Tennessee State Capitol and convinced general William Nelson, the commander of the Unionist troops, to raise "Old Glory" to the Capitol flagstaff. 
polymath Benjamin Franklin, and Confederate general Robert E. Lee, among others. ${ }^{19}$ His wife Maria crowned the finished patriotic mausoleum by knitting a small flag in memory of "Old Glory," which flew for years from a staff atop their little home. Primo evokes it in one of his poems:

It freely waves upon the mast,

Undimmed its starry bright,

No stains obscure its red and blue,

No treason blots its white. ("Hats Off")

The best example of Bartolini's "Americanization"-his process of integration and cultural hybridization-is in one of his most patriotic compositions: a poem dedicated to the Italian flag and later conspicuously amended, most probably soon after the experience of the war. ${ }^{20}$ The poem shows how Primo's identity resolutely shifted toward America, which replaces Italy as "the land where my fathers lie" (2). Moreover, the Italian tricolour flag loses its green, which traditionally represents hope in Italian folklore, in favour of the colour blue, which often symbolizes the same feeling in American culture. The addition of non-rhyming lines at the end of each stanza, as a patriotic, varied refrain on the themes of freedom and the fight for justice, vouches for a vigorous civil commitment to the American cause: the experience of the war had kindled in Bartolini and in his fellow "Eye-talians" of Nashville and the Vancouver Barracks fires of Americanism, while the flame for the old homeland had diminished to a sentimental flicker. The setting of the poem changes, and the "fields" so longed for hint at the vast plains of Tennessee, while the "Latin" sky seems to suggest a Southern blissful ambience, more than a Mediterranean heaven. Imbued with classical culture, Bartolini tried to use an iambic tripod, as his revision of the poem in the vertical handwritten note

\footnotetext{
${ }^{19}$ As confirmed by Bartolini himself in an interview given to H. B. Teeter, a correspondent for The Nashville Tennessean Magazine, Bartolini found most of these stones, along with "fossils, a broken axe blade and a huge cannon ball inscribed '1914'," during the excavation works carried out to build the foundations of his house (Teeter). The house was demolished at the end of 2014 to make space for a new residential complex.

20 The type of paper used confirms this dating. Bartolini's poems written before the war were jotted down on light blue square notebook sheets or on letterhead from various hotels (The Hermitage, The Savoy, etc.). During the war, Bartolini used the same type of thin brownish paper, like the one he used on which to type "My Italian Flag" (see Figure 1).
} 
shows (see Figure 1). The traditional rhythm of classical choral poetry suggests the existence in the author of a patriotic desire for inclusion, a poetic voice that now felt perfectly integrated among the million voices of his new homeland.

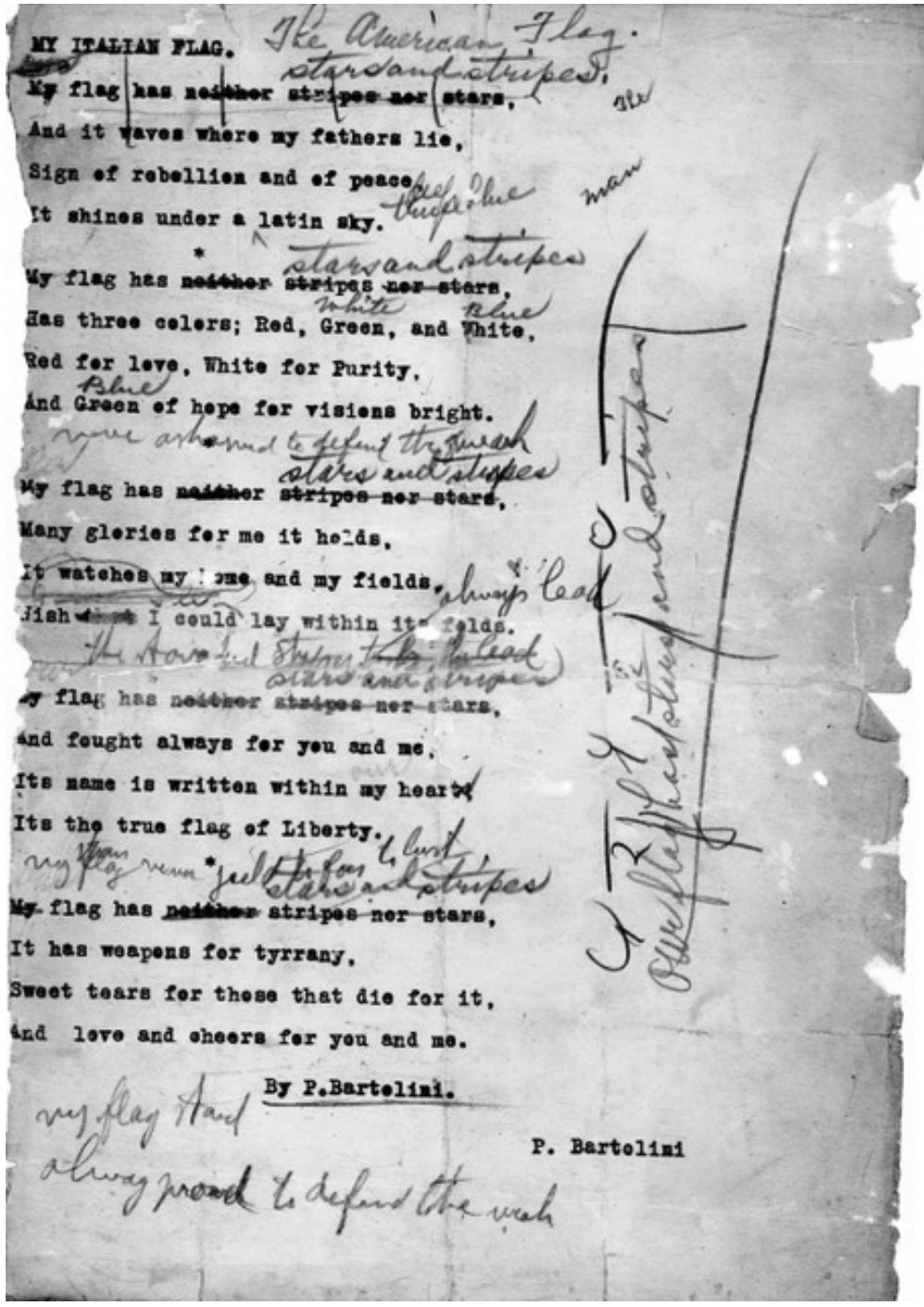

Figure 1. Primo Bartolini, "My Italian Flag" (with ms. corrections), circa 1918-circa 1931. Courtesy of Nashville Metropolitan Archives, Nashville, Tennessee 


\section{A Paradigm for Italian Integration in the American South}

Primo Bartolini's migration experience, along with those of his fellow Italians who settled in Nashville, is useful to gauge the degree of integration and the social status of Italians in the area. Various documents, including the Dillingham Report (possibly the most racially-biased among them), show an early economic and social integration in rural areas that has rarely been attained by other Italian colonies in America, especially in the American South. The relationship between Italians and their neighbours in Alabama, Kentucky, Mississippi, and Louisiana has indeed been consistently problematic: Italian immigrants were often ghettoized in shantytowns not unlike the Little Italies of New York, Chicago, and San Francisco. For instance, episodes of discrimination were recorded in the Italian colony of Birmingham, Alabama, which is less than 200 miles away from Nashville. ${ }^{21}$

As demonstrated by the urban layout of the small centre of Thomas, a densely populated suburb of Birmingham, Italians were marginalized and openly regarded as racially inferior by local whites. Workers' huts occupied three parallel streets: the first one was for the Anglo-Americans, the second one for the Italians, and the last one for the African Americans. According to several articles published in the local Italian periodical Il Gladiatore (1928), the Anglo-American community would frequently single out the "dirty Eye-talians" for poor personal hygiene; also, they were often falsely accused of crimes, beaten by hostile policemen, and jailed.

The editor of the periodical urged his fellow Italians to comply with "good citizenship rules" to avoid discrimination. Among these good habits for Italians was that of sufficiently maintaining one's personal hygiene; one article, published in 1929, is titled "I denti" and gives instructions about maintaining good oral hygiene. Finally, a short note published in 1933 confirms that "nessun lingiaggio" [sic] (no lynching) was recorded in the state of Alabama on that year, a sign that lynching of Italian immigrants had been the norm until the early Thirties (“Alabama: Nessun Lingiaggio Nel 1932").

Occasionally, Italians were also injured in brawls with African Americans, who saw Italians as job-stealing aliens in a struggle for survival (Fede 236; Rolle 89-90). However, in Birmingham, the Italian American community and its African American counterpart also enjoyed long years of fruitful and peaceful

${ }^{21}$ An account is given in Brera, “'Il Gladiatore” 155-157. 
collaboration. ${ }^{22}$ In his 1986 study on social mobility among Italian immigrants in Birmingham, Robert J. Norrell showed that Italian integration in Alabama had been primarily economic: most of the newcomers from Italy were especially entrepreneurial and ready to climb the social ladder (Norrell 105-106).

One trait of the Italian workers in the South that appears also to have characterized the Nashville community was their ability to move out of menial works and into petty entrepreneurship, such as the numerous "Mom and Pop" stores that mushroomed in town and quickly became a symbol of progress among Italian immigrants. In Birmingham, Italians even profited from their relationship with African Americans; in fact, Italians were less racially prejudiced than other native white ethnic groups who refused to deal with African Americans and establish businesses in their areas. Therefore, African Americans shopped at Italian grocery stores, thus providing Italians with the funds to expand their businesses or establish new ones.

The Nashville economy was largely based on farming and service jobs, whereas Birmingham was an industrial city. However, Italians in Tennessee similarly blended very quickly into their adoptive societies: firstly, they established cultural and linguistic bonds with the locals; secondly, they fully exploited the economic market, quickly becoming influential American citizens.

By the Fifties, the Italian-American Club of Nashville counted among its members some leading local businessmen, such as Dominick Petruccelli, a prominent figure in the food industry who, in his youth, had been an enthusiastic patriot serving for the Allied cause in the Great War, and "Pat" Reale, a wholesale jeweller. The Italian American organization was devoted to charitable activities and was open to Nashvillians of any descent. An article published in the Nashville Tennessean Magazine in 1954 regarded it as being "as American as the Whittlers' club at the village store" (Hinton 24).

The case of Nashville consolidates and expands our knowledge of Italian participation in public life, and shows the desire for integration expressed by Italian Americans in a thriving southern city at the turn of the twentieth century. Soon after their arrival, Italians were ready to sever most of their identity ties with the motherland in order to be regarded as fully American before they were eventually naturalized. As Evaristo Ghidoni's experience shows, learning the local language was the crucial step. Ghidoni's relentless work in favour of better schooling for the

\footnotetext{
${ }^{22}$ See Fede 236-242.
} 
Italian community and, more importantly, his efforts to teach fellow Italians the English language make a strong case against the stereotypical view of an Italian community that isolates itself from native whites of other ethnic groups.

The Italians in the Nashville area, while preserving their cultural identity, gradually gave up their social and patriotic "Italianness," which was often limited to displaying symbols and banners at public ceremonies (e.g., the celebrations in honour of Christopher Columbus). Furthermore, they expressed the desire of gaining better knowledge of the language that they regarded as a pivotal means to access the economic market.

Another strong boost to the Americanization of the Nashville Italians came from their public engagement after the outburst of the First World War: as aspects of their Italian identity began to fade, these were quickly replaced by a newly found American patriotic spirit, often rooted in old Risorgimento ideas of rebellion and the fight for freedom. In this context, Primo Bartolini represents a unique example of the Americanization of an Italian immigrant. An extraordinarily gifted individual, imbued with a love of Italian culture but also a willingness to become American, this Italian bard expressed through his poems the integration trajectory of many immigrants. At first, his poetic voice revealed a nostalgic love for the country he had left; then, once he absorbed American patriotism, it reflected his unconditional admiration for and a willingness to integrate into his new country. Most of Bartolini's poetry is consolatory and self-referential, with themes and topics such as the melancholic remembrance of the Italian landscape and the depiction of the Southern one; the love for the mother and an idealized woman-often Primo's wife, Maria. Bartolini allegedly published some of his poems in two collections titled Scattered Leaves and Crumbs. ("Primo Bartolini Is Head of Diaz Club") No copies have survived of these anthologies, whose alleged title recalls both the poetry of minimal fragments canonized by Petrarch (Rerum Vulgarium Fragmenta) and the title of the iconic American collection Leaves of Grass published by Walt Whitman between 1855 and 1892 .

When the war broke out, Bartolini followed in the footsteps of many American poets of the time: inspired by the conflict, he became more and more passionately engaged in his "Anti-Hun" tirades at the Italian Union and was widely recognized, as the printed sources already mentioned in this essay document, as a public "oracle" (Van Wienen 6), holding significant influence over both the Italian and the American publics. 
Along with his verses, Bartolini's numerous patriotic activities and displays of Americanness are proof of the important role played by Italians, even when they were not fighting in the Alps, in keeping communities together in spirit while helping their members merge with American society. Primo never witnessed the carnage of the Western front, confined as he was at Vancouver Barracks; however, he directly engaged with the social and political conditions of the time, developing his civil commitment mainly on a rhetorical level and rooting his war poems in the Risorgimento ideal of war as a proving ground for young people's manhood. In his poetic imagery, soldiers went to war willing to die, but not so much to kill, as one of his French-language poems shows:

[...] Ils sont nos braves jeunes gens dans les tranchées, Ah! Le bonheur profond de donner sa vie Il[s] sont là-bas, là-bas, dans la nuit d'hiver, À la défense de la liberté de la patrie.

Quand ils tombent, ils n'ont pas de deuils, de regrets Ils meurent calmes, heureux dans leur conscience.

Ah! Posez, posez des fleurs sur leurs tombeaux, $\mathrm{O}$ jeunes filles, posez les fleurs de l'espérance. ${ }^{23}$

The rhetorical pattern of this poem is inherited from the French patriotic tradition, of which the "Marseillaise" is the best-known example. Bartolini was a scholar in French literature, which he had studied in Switzerland, and was undoubtedly familiar with some literary figures in this tradition. ${ }^{24}$ Consistently with Primo's nostalgic verses, the poetic voice also longs for places "over there."

As many American politicians, poets, and political activists who could only "observe" the Great War from overseas, Bartolini probably failed to appreciate the carnage that was taking place in the trenches. His patriotism remained somehow

23 "They are our brave young men in the trenches, / Ah! The profound joy in giving one's own life! / They are over there, over there in the winter night, / To defend the freedom of the Fatherland. / When they fall, they don't feel grief, regrets / They die calmly, happy in their consciousness. / Ah! Place, place flowers on their graves, / O girls, place the flowers of hope." (My translation).

${ }^{24}$ The poem's last line, in particular, could be reminiscent of the second book of Marcel Proust's $\grave{A}$ la recherche du temps perdu, titled $\grave{A}$ l'ombre des jeunes filles en fleurs, which was published in 1915. 
mannerist and faithful to the idea of "Dulce et decorum est / Pro patria mori" that was harshly indicted as "the old Lie" by Wilfred Owen's famous poetic anti-war manifesto. ${ }^{25}$ The "thousand boys" of Bartolini's verses, the "deads" who fought the "foe" in the Flanders and in the Alps while "Old Glory" was flying for "Liberty" are indeed the same ones who were lauded by the pro-war American rhetoricians for making the world "safe for democracy" and who appear in many poems about the First World War (Van Wienen 23). Dialoguing with his fellow poets, Primo Bartolini played an active part in both his own Americanization and that of the Nashville Italians. Today, after a few decades of oblivion, his poetry rightfully claims its place among the lost voices of the Great War.

\section{The University of Edinburgh/University of Toronto}

\section{Works Cited}

Aguglia Beavers, Theresa. "The Italians of the Birmingham District." MA Thesis. Typescript. Samford University, Aug. 1969.

“Alabama: Nessun Lingiaggio Nel 1932." Il Gladiatore 7 Jan. 1933.

Brera, Matteo. " 'Il Gladiatore' e la costruzione dell'identità italo-americana nel distretto di Birmingham, Alabama." Archivio Storico dell'Emigrazione Italiana 13 (2017): 154-162.

. "Italiani in Tennessee tra identità nazionale e americanizzazione. Una prima indagine." Archivio Storico dell'Emigrazione Italiana 12 (2016): 7587.

Coleman Ellison, Rhoda. "Little Italy in Rural Alabama." Alabama Heritage 2 (1986): 34-47.

\footnotetext{
${ }^{25}$ Wilfred Owen is one of the greatest writers of war poetry in the English language. At the end of 1916, he was sent to France where he endured the horrors of the front line and wrote out of his intense personal experience as a soldier. His poetic production, which he composed in a mere 15 months, describe the physical, moral, and psychological trauma of the Great War. The most iconic of Owen's poems is arguably Dulce et decorum est, thought to have been written between 8 October 1917 and March 1918, whose last few lines read, "My friend, you would not tell with such high zest / To children ardent for some desperate glory, / The old Lie; Dulce et Decorum est / Pro patria mori” (Walter 141-142).
} 
Cullom, Burr. I'll Call Her Old Glory, Boys, Old Glory: The Story of How Old Glory Got Its Name. N. p.: 1937.

Deaglio, Enrico. Storia vera e terribile tra Sicilia e America. Palermo: Sellerio, 2015. Fede, Frank Joseph. Italians in the Deep South: Their Impact on Birmingham and on American Heritage. Montgomery, Alabama: River City Publishing, 2001. Fleenor, Michael E. East Nashville. Charleston, NC: Arcadia Publishing, 1998. "For Betterment of Italians in Nashville." The Nashville Tennessean 27 Feb. 1908. "Free Night School for Local Italians." The Nashville Tennessean 27 Aug. 1908. Hinton, Elmer. "Strangers No More: Though Nashville Italian-American Club Has Outlived Its Original Function, It Has Taken on New Emphasis." The Nashville Tennessean Magazine 24 Jan. 1954: n. pag.

"I denti." Il Gladiatore [Birmingham, AL] 10 Aug. 1929.

"Italian Drafted, Breaks into Poetry." The Nashville Tennessean 29 June 1917.

"Italians Ready to Join the Army." The Nashville Tennessean 13 March 1917.

"Italians Send Aid Across the Sea." The Nashville Tennessean 4 Jan. 1909.

"Local Italian Has Hope for Country." The Nashville Tennessean 26 Nov. 1917.

"Mrs. Bartolini Services Today." The Nashville Tennessean 23 Sept. 1969.

"Nashville Bard Awarded Prize." The Nashville Tennessean 18 July 1918.

The Nashville Directory. Vol. 52. Nashville: Marshall \& Bruce, 1915.

. Vol. 53. Nashville: Marshall \& Bruce, 1916.

"Nashville Italians to Meet Sunday." The Nashville Tennessean 19 Jan. 1915.

National Archives and Records Administration. "United States Census, 1900." NARA microfilm publication T623. Washington, D.C.: n. d. 27 March 2015.

Norrell, Robert J. "Steelworkers and Storekeepers: Social Mobilities among Italian Immigrants in Birmingham." In The Italian Americans Through the Generations. Ed. Rocco Caporale. New York: The American Italian Historical Association, 1986. 98-111.

"Opposes the Study of German Language." The Nashville Tennessean 10 March 1918.

"Primo Bartolini Buys Savings Certificates." The Nashville Tennessean 3 Feb. 1918. "Primo Bartolini Drafted: Proud to Serve Country." The Nashville Tennessean 7 Aug. 1917.

"Primo Bartolini Is Head of Diaz Club." The Nashville Tennessean 28 Oct. 1917. "Primo Bartolini Leaves from Vancouver Barracks." The Nashville Tennessean 31 July 1918. 
"Proud of Part Italy Played." The Nashville Tennessean 9 Dec. 1918.

Rebori, John. The Italians of Knoxville, Tennessee. Ts. with ms. notes. McClung Collection, East Tennessee History Center, Knoxville, Tennessee.

"Says Italians Are Now United." The Nashville Tennessean 11 Nov. 1917.

"Silk Flag Given to Primo Bartolini." The Nashville Tennessean 27 June 1918.

Sterba, Christopher M. Good Americans: Italian and Jewish Immigrants during the First World War. Oxford: Oxford UP, 2003.

Teeter, H. B. "C[avalier] Primo Bartolini Memorialises William Driver." The Nashville Tennessean Magazine 1 Jan. 1953: 48-49.

United States Immigration Commission (1907-1910). "The Dillingham Commission Reports.”. Immigrants in industries: Part 24: Recent immigrants in Agriculture (in two volumes: vol. 1. Serial Set Vol. 5682). Washington, D.C.: Government Printing Office, 2003. ProQuest ebrary. 25 March 2015. http://www.ebrary.com/stanford/ Dillingham 1.html.

Van Wienen, Mark W. (ed.). Rendezvous with Death. American Poems of the Great War. Urbana and Chicago: U of Illinois P, 2002.

Walter, George (ed.). The Penguin Book of First World War Poetry. London: Penguin, 2006.

Wills, Ridley, II. The Hermitage at One Hundred: Nashville's First Million-Dollar Hotel. Franklin, Tennessee: Providence House Publishers, 2009. 